TECHNICAL REPORT

\title{
HOME TEST KIT FOR DUCT LEAKAGE
}

John W. Andrews

April 1997

RECEIVED

JUN 24997

O.STI

Prepared for:

Building Equipment Division

Office of Building Technologies,

State and Community Programs

U.S. Department of Energy

MASTER

Under Contract No. DE-AC02-76CH00016

DEPARTMENT OF ADVANCED TECHNOLOGY

BROOKHAVEN NATIONAL LABORATORY, ASSOCIATED UNIVERSITIES, INC.

P.O. BOX 5000, UPTON, NEW YORK 11973-5000

Energy Efficiency and Conservation Division

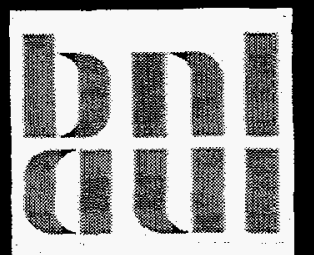

Prepared for the U.S. Nuclear Regulatory Commission

Office of Nuclear Regulatory Research

Contract No. DE-AC02-76-CH00016 


\section{DISCLAIMER}

This report was prepared as an account of work sponsored by an agency of the United States Government. Neither the United States Government nor any agency thereof, nor any of their employees, nor any of their contractors, subcontractors, or their employees, makes any warranty, express or implied, or assumes any legal liability or responsibility for the accuracy, completeness, or usefulness of any information, apparatus, product, or process disclosed, or represents that its use would not infringe privately owned rights. Reference herein to any specific commercial product, process, or service by trade name, trademark, manufacturer, or otherwise, does not necessarily constitute or imply its endorsement, recommendation, or favoring by the United States Government or any agency, contractor or subcontractor thereof. The views and opinions of authors expressed herein do not necessarily state or reflect those of the United States Government or any agency, contractor or subcontractor thereof. 


\section{HOME TEST KIT FOR DUCT LEAKAGE}

John W. Andrews

April 1997

\section{MASTER}

Prepared for:

Building Equipment Division

Office of Building Technologies,

State and Community Programs

U.S. Department of Energy

Under Contract No. DE-AC02-76CH00016

\section{DISCLAIMER}

This report was prepared as an account of work sponsored by an agency of the United States Government. Neither the United States Government nor any agency thereof, nor any of their employees, makes any warranty, express or implied, or assumes any legal liability or responsibility for the accuracy, completeness, or usefulness of any information, apparatus, product, or process disclosed, or represents that its use would not infringe privately owned rights. Reference herein to any specific commercial product, process, or service by trade name, trademark, manufacturer, or otherwise does not necessarily constitute or imply its endorsement, recommendation, or favoring by the United States Government or any agency thereof. The views and opinions of authors expressed herein do not necessarily state or reflect those of the United States Government or any agency thereof. 


\section{DISCLAMIER}

Portions of this document may be illegible in electronic image products. Images are produced from the best available original document. 


\section{ABSTRACT}

An inexpensive device whose purpose is to test for duct leakage in the home is described. This device is intended for use by homeowners and others untrained in the art of duct testing. While not as accurate as testing done by professionals, it should be able to give the homeowners enough information to justify a decision whether or not to call on professional assistance for further testing and possible remediation of their duct systems. The device has been reduced to practice. 
Abstract $\ldots \ldots \ldots \ldots \ldots \ldots \ldots \ldots \ldots \ldots \ldots \ldots \ldots \ldots$

List of Tables $\ldots \ldots \ldots \ldots \ldots \ldots \ldots \ldots \ldots \ldots \ldots \ldots \ldots \ldots$

List of Figures $\ldots \ldots \ldots \ldots \ldots \ldots \ldots \ldots \ldots \ldots \ldots \ldots \ldots \ldots$

Introduction $\ldots \ldots \ldots \ldots \ldots \ldots \ldots \ldots \ldots \ldots \ldots \ldots \ldots$

The House Pressure Test $\ldots \ldots \ldots \ldots \ldots \ldots \ldots \ldots \ldots \ldots$

Description of Homeowner Test Kit . . . . . . . . . . 4

Some Preliminary Test Results $\ldots \ldots \ldots \ldots \ldots \ldots \ldots \ldots \ldots$

Further Research Needs . . . . . . . . . . . . . . . . . .

References . . . . . . . . . . . . . .

\section{LIST OF TABLES}

1. Values of pressure obtained from manometer and test kit . . . . 6

2. Duct leakage values obtained from House Pressure Test . . . . . 7

3. Duct leakage values from home test kit . . . . . . . . . 8

\section{LIST OF FIGURES}

1. Home test kit in attic opening (top view) $\ldots \ldots \ldots \ldots \ldots \ldots$

2. Home test kit in attic opening (bottom view) $\ldots \ldots \ldots \ldots \ldots \ldots$

3. Using duct blower and manometer to establish calibration curve. . . 12

4. Test kit ready for use in measuring duct leakage. . . . . . . . . . .

5. Closeup of magnet weights bringing plastic down to a neutral position 


\section{INTRODUCTION}

Energy losses in residential duct systems are estimated to total $\$ 15$ billion annually. [Andrews and Modera 1991] Several barriers stand in the way of reducing these losses. One barrier is that measuring the losses in a particular house's duct system has required specialized equipment and training. Another barrier is that in most areas of the country, qualified vendors of duct repair services are not easy for the average homeowner to identify.

A recent advance has been the development of a more-rapid test method for measuring duct leakage. Called the House Pressure Test, it is slated to be incorporated in a comprehensive national test method for thermal distribution efficiency being developed under the aegis of the American Society of Heating, Refrigerating, and Air-conditioning Engineers (ASHRAE), with support from the U.S. Department of Energy. [ASHRAE 1997]

The House Pressure Test makes use of pressure changes in the house and in the duct system, together with the air leakage flow coefficient of the house envelope, to calculate the leakage flows from the outside to the return duct, and from the supply duct to the outside, under normal system operation. The required measurements are of three types:

- The pressure in the house with respect to the (vented) attic, under three operating conditions: 1) with the furnace fan off; 2) with the furnace fan on; and 3) with the furnace fan on and the return register(s) partially blocked.

- The pressure at the midpoint of the return duct, and at a representative point in the supply duct, under the second and third operating conditions described in the preceding bullet.

- The air leakage flow coefficient of the house envelope (blower door test).

The pressure measurements can be made quickly and easily with a digital manometer and a set of plastic hoses. The flow coefficient measurement requires a blower door. The philosophy behind the House Pressure Test is that in any situation where home weatherization or other energy-efficiency improvements to the envelope are contemplated, the blower door measurement would be done anyway. Thus, the House Pressure Test can get the duct leakage rates with only a small additional investment of technician time.

It does, however, require that the homeowner take the initiative in locating and hiring qualified duct testers. This is a major roadblock, since homeowners are likely to have other things on their minds. The need was seen, therefore, for a simple entry-level means whereby homeowners could either be motivated to seek professional assistance with their duct systems because problems are shown to be likely or else be reassured that their duct energy losses are probably low.

This report describes a simple cardboard-and-plastic device that can give approximate values for the measurements described in the first bullet. Moreover, it can obtain these values without the need for specialized test equipment such as a digital manometer, and it should be usable by untrained personnel such 
as a typical homeowner. The device conceptually could be sold in hardware stores and comparable outlets at a price of $\sim \$ 10$. Written instructions on the use of the device would be included. Also included in the package, in the conceptual delivery system model of which the device is an element, would be information on how to obtain professional assistance in the event that the home test shows a probability of significant duct leakage. A mechanism would need to be set up whereby firms desiring to be listed as sources of duct repair services would obtain certification of their competence.

\section{THE HOUSE PRESSURE TEST}

The House Pressure Test was conceived by Mark Modera of Lawrence Berkeley National Laboratory and is in the public domain.[Modera and Byrne 1997] It uses the house itself as a pressure test chamber in which the effect of operating a duct system under varying conditions is used to assess duct leakage. As mentioned above, the pressure difference between the house and the attic (used as a proxy for the outside ambient) is measured under three test conditions: 1) with the furnace fan off; 2) with the furnace fan on; 3 ) with the furnace fan on and the return register(s) partially blocked off with newspaper or a piece of cardboard.

One significant piece of information is obtained just from the effect on the house pressure when the furnace fan is turned on. If this raises the pressure inside the house, it means that there is more leakage on the return side of the duct system than on the supply side. That is, more air is being drawn into the duct system from the outside (in the return ducts) than is being discharged to the outside from the duct system (on the supply side). This excess air is blown into the house and thereby raises its pressure. Similarly, if the pressure inside the house drops, it means there is more leakage on the supply side of the duct system than on the return. If the pressure does not change, it means that return and supply leakage rates are equal.

This is important information, but it is not enough to give us the supply and return leakage rates separately. It only gives us their algebraic sum (with return leaks counted as negative). For example, if the pressure in the house does not change when the furnace fan comes on, it could mean there is no leakage in either side of the duct system. But it could also mean that there is much leakage on both sides but that these two leakage rates are equal.

In order to provide another equation to solve for supply and return leakage rates individually, the house pressure test specifies that the return register now be blocked off enough to cause the pressure within the return duct to drop from the -30 to $-50 \mathrm{~Pa}$ that is typical during normal operation to about $-100 \mathrm{~Pa}$. (The SI unit of pressure, the pascal, which is equal to one newton per square meter or 0.004 inches of water column, is universally used in duct testing, even when other quantities, such as flow rates, are measured in IP units.)

The return-blocked test provides a new operating regime that can differentiate, for example, between the two conditions discussed immediately above. If there is no duct leakage at all, turning on the furnace fan would have no impact on house pressure whether or not the return register is blocked. But if there are high (and equal) rates of supply leakage and return leakage under normal operation, blocking the return register will cause the pressure in the return duct to become more negative, increasing the return leakage. It will 
also cause the pressure in the supply duct to become less positive, decreasing the supply leakage. So now the leakage rates will be unequal, with return leaks dominating, and this will cause the house pressure to rise.

So in order to execute the House Pressure Test, it is necessary to have a way to measure the house-tooutside pressure difference, to an accuracy of a few tenths of a pascal. In the House Pressure Test, this is done by running a plastic hose to the attic and using it as a proxy for the outside. A digital manometer is then used to measure the pressure difference between the attic and the inside of the house. The homeowner's test kit described in this report substitutes a low-cost item that will eliminate the need for the manometer, although at significant sacrifice of accuracy. It should be accurate enough, however, to be able to tell homeowners whether or not duct repair is likely to be needed in their homes.

In addition to the three house-to-attic pressure differences mentioned above, two duct pressure ratios are also needed in the calculation. One is the ratio (with the furnace fan on) of pressure in the return duct when the return register is blocked to that when the register is unblocked. The other is a similar ratio for the supply duct. The former ratio is obtained by running a hose into the return duct approximately halfway to the furnace and measuring the pressure when the return is unblocked and again when it is blocked. The latter is obtained by momentarily blocking one of the supply registers and taking a pressure reading inside it, under both return-unblocked and return-blocked conditions.

The home test kit described in this report cannot make these duct pressure measurements. However, these ratios tend to fall within predictable ranges, and even without precise values one should still be able to obtain, in most cases, enough information to guide the homeowner to a decision on whether or not to call for further testing.

The one additional piece of information, the envelope flow coefficient measured with a blower door, will also not usually be available in a homeowner-conducted test. In the House Pressure Test, the duct leakage scales linearly with this coefficient. It is envisioned that a preliminary estimate of its value, obtained from the house's size, age, style, and state of repair might give a good enough "ballpark" value to enable reasonable estimates to be made for the purpose envisioned here, namely, to give the homeowner a first-cut answer to the question of whether he or she should be concerned about duct leakage. At the very least, it will permit an estimate of duct leakage's importance, relative to envelope leakage, in the overall energyloss budget of the home. 


\section{DESCRIPTION OF HOMEOWNER TEST KIT}

The homeowner test kit is intended to provide a good-enough measurement to tell the homeowner whether duct energy losses are likely to be serious in his or her house. It uses materials that could be supplied in a package to be sold in stores for under $\$ 10$. The test kit is conceived as part of a total system in which the consumer would do the test and then, if the results are positive, call an 800 number supplied with the kit to get a list of qualified practitioners in the area. This is similar to what the U.S. Environmental Protection Agency now does with radon test kits.

The test kit consists of a baffle of cardboard or other easily trimmable material that is cut to size by the homeowner and inserted into the home's attic access hatch. It will come with a rectangular hole of predetermined size that is pre-cut into the baffle and covered with a sheet of thin plastic. A 1/2- to 1-mil thickness such as is commonly sold in supermarkets for food wrapping works well. The plastic sheet is not to be tautly stretched over the hole but rather should be somewhat flaccid, so that the observer can tell whether it is pushed up toward the attic or pulled down toward the living space by the pressure difference between the house and the attic. If under any test condition, the plastic sheet is pushed into the attic, the house is pressurized; if it is pulled toward the living space, the house is depressurized. Figures 1 and 2 show a mockup of such a baffle with its thin-film plastic insert.

As described so far, this device is able to tell the sign of the pressure difference between the house and the attic under each of the three test conditions--furnace fan off; fan on; and fan on with the return register(s) partially blocked. Specification of how much to block the return register is discussed later on in this report.

Now, however, it is useful to note that there is a way to quantify the pressure difference between the house and the attic, beyond just knowing its sign, if this pressure difference is positive. This is accomplished by providing a set of weights with the test kit. These weights, typically 1 gram each, would be made from strips of plastic magnet material such as is used in commerce for various purposes, the most common one seen by consumers being "refrigerator magnets." If the plastic sheet is seen to bow upward into the attic, weights are attached to its center until this center, with its weights, is pulled down so that it is on a level with the cardboard baffle. The first weight is attached to a strip of double-sided tape at the center of the plastic "window." Additional weights adhere to the first via magnetism.

To use this scheme, it is necessary to establish a calibration curve relating the pressure difference to the amount of weight needed to balance the pressure difference. Figure 3 shows how this was done. An adjustable fan known as a duct blower, which is normally used in duct pressurization testing, was used here to establish pressure differences between the house and the attic ranging from 0 to 6 pascals. It was found that the calibration curve was very nearly a straight line passing through the origin, with a slope of 0.5 pascals per gram. Accuracy is estimated as \pm 0.5 pascals for pressures below 2 pascals, and \pm 1 pascal for higher pressure differences. 
We now have a mechanism that can measure the pressure difference between the house and the attic, if the house pressure exceeds that in the attic. If the attic pressure exceeds that in the house, the plastic will bow downward, and adding weights will of course only make it bow downward more tautly. In that case, we must content ourselves with just knowing the sign of the pressure difference and not its magnitude. However, this is not seen as a major drawback for the following reasons:

1) If the tests are performed when the inside of the house is warmer than the outside, stack effect will make the plastic bow upward initially (when the furnace fan is off).

2) This being the case, if the plastic bows downward when the furnace fan is turned on, this is already an indication that there is significant leakage on the supply side. If it still bows upward, the balancing test can be used.

3) Partially covering the return register (with the furnace fan on) always biases the house toward more positive pressure (or less negative pressure) than it had when the fan was on and the register was unblocked. It is thus very likely that for this test the plastic will bow upward, even if it didn't before.

Admittedly there will be cases where the test is inconclusive, for example if the test is performed in summer and the plastic bows downward for all three tests. Good advice to the homeowner would be to perform the test during the colder half of the year if possible. Then the stack effect will give the house-attic pressure difference enough of an "offset" from zero that the weighting procedure will prove effective in nearly all cases.

\section{SOME PRELIMINARY TEST RESULTS}

The device was tested in a local home with forced-air heating. This home has a pull-down stairway up to the attic, so some ingenuity was needed to achieve an opening to the attic and yet have a tight seal. Figure 4 shows how this was done. The stairway cover was pulled down about 2 inches (enough to give a sufficient opening to the attic) and then the edges were taped over and, at one end, boxed in with a cardboard collar. The cardboard pressure measurement device was attached to the bottom of the collar. In Figure 4 one can see the plastic bowing upward because of the natural pressure difference due to stack effect. (The test was done in January.) Figure 5 is a closeup of the plastic, showing it pulled down to a neutral level with weights.

In this field test, the home test kit results were compared with the results of the House Pressure Test. In the House Pressure Test, the pressure differences between the house and the attic under the three fan conditions, as well as the duct pressures required for this test, were measured with a digital manometer.

For each furnace fan condition specified by the House Pressure Test, the home test kit was used to get a pressure difference value, and the digital manometer was used to get a more accurate value. The Table 1 compares these values. 
The House Pressure Test specifies blocking the return register until the pressure in the return duct is -100 pascals. This is not possible with the home test kit, because it doesn't measure the return duct pressure. Instead, three measurements were taken, with $70 \%, 80 \%$, and $90 \%$ of the the return register's face area blocked off. For each of these conditions, the return duct pressure was measured in the House Pressure Test. These values were $-90,-115$, and -142 pascals, showing that the nominal -100 pascal value would have been achieved at about $74 \%$ blockage. It is important to note that the House Pressure Test is not based on return pressure being exactly -100 pascals. This is merely a nominal value intended to be great enough to get reasonably accurate results but not so great as to damage the duct system. For the test kit, we tentatively would advocate specifying $75 \%-80 \%$ blockage of the return register.

Table 1. Values of pressure obtained from digital manometer and home test kit.

\begin{tabular}{|l|l|l|l|l|l|l|}
\hline $\begin{array}{l}\text { Furnace Fan } \\
\text { Condition }\end{array}$ & \multicolumn{2}{|l|}{$\begin{array}{l}\text { Digital Manometer (Pressures in } \\
\text { pascals) }\end{array}$} & \multicolumn{2}{l|}{$\begin{array}{l}\text { Home Test Kit (Pressures in } \\
\text { pascals, weights in grams) }\end{array}$} \\
\hline & $\begin{array}{l}\text { House- } \\
\text { Attic } \Delta \mathrm{P}\end{array}$ & $\begin{array}{l}\text { Supply Duct } \\
\text { Pressure }\end{array}$ & $\begin{array}{l}\text { Return Duct } \\
\text { Pressure }\end{array}$ & $\begin{array}{l}\text { Plastic Up } \\
\text { or Down }\end{array}$ & $\begin{array}{l}\text { Weight to } \\
\text { Balance }\end{array}$ & $\begin{array}{l}\text { House- } \\
\text { Attic } \Delta \mathrm{P}\end{array}$ \\
\hline ON & 2.27 & 40 & -56 & Up & 6 & 3 \\
\hline OFF & 1.63 & not needed & not needed & Up & 2 to 4 & 1.5 \\
\hline ON & 2.61 & 40 & -56 & Up & 6 & 3 \\
\hline OFF & 1.53 & not needed & not needed & Up & 4 & 2 \\
\hline ON, RB70* & 4.05 & 35 & -90 & Up & 9 & 4.5 \\
\hline ON, RB80* & 4.81 & 32 & -115 & Up & 10 & 5 \\
\hline ON, RB90* & 5.37 & 28 & -142 & Up & 10 to 11 & 5.25 \\
\hline OFF & 1.27 & not needed & not needed & Up & 4 & 2 \\
\hline
\end{tabular}

* RB70, RB80, and RB90 mean $70 \%, 80 \%$, and $90 \%$ of the face area of the return register was blocked.

Using the algorithm associated with the House Pressure Test, the values shown in Table 2 were obtained for supply and return leakage. This algorithm requires that the envelope leakage flow coefficient be known. Results of a previously conducted blower-door test were used in these calculations; this value, was 1790 CFM50 or $147 \mathrm{cfm} / \mathrm{Pa}^{-0.65}$. Note that returns leak inward; hence the minus signs. 
Table 2. Duct leakage values obtained from House Pressure Test.

\begin{tabular}{|l|l|l|}
\hline Test Condition & Supply Leakage (cfm) & Return Leakage $(\mathrm{cfm})$ \\
\hline RB70 & 300 & -368 \\
\hline RB80 & 234 & -304 \\
\hline RB90 & 186 & -258 \\
\hline
\end{tabular}

It is to be emphasized that the House Pressure Test should ideally give the same values for supply and return duct leakage regardless of the degree to which the return is blocked during that part of the test. The supply and return leakage values are the leakage flow rates calculated to occur under normal operation. It can be seen that the House Pressure Test is not perfectly accurate, and that some variation in these quantities must be expected. But it is considered good enough for its intended use, namely, getting an overall value for duct efficiency.

The furnace fan flow rate was separately measured to be $900 \mathrm{cfm}$ in this house. Therefore, the above results can be cast in the following form: the supply duct leakage is probably between $21 \%$ and $33 \%$ of fan flow, and the return duct leakage is probably between $29 \%$ and $41 \%$ of fan flow. Anything over $10 \%$ is considered undesirable, and $20 \%$ or more represents serious leakage. So in this case we can be fairly sure that this house ought to have its ducts sealed.

The test kit results were considered next. The quantity $R$ is the ratio of return duct pressures (return blocked to unblocked), raised to the 0.6 power. This was assumed, on the basis of field tests in 8 Long Island homes [Andrews 1996] to fall in the range 1.4 to 1.8. The quantity $S$ is the ratio of supply duct pressures (return blocked to unblocked) raised to the 0.6 power. This was assumed, again on the basis of limited field-test data, to fall in the range 0.7 to 0.9 . The values of duct leakage resulting from the test kit, for each combination of $\mathbf{R}$ and $\mathbf{S}$ values and return blockage, are given in Table 3.

In getting the numbers in Table 3, we "cheated" a little in that we used the blower door result for the envelope leakage coefficient. In an actual test with the homeowner test kit, this variable would have to be estimated. A rule of thumb used by some workers in the field is to expect a specific envelope effective leakage area (ELA) of $4 \mathrm{~cm}^{2}$ per $\mathrm{m}^{2}$ of floor area for new construction. This translates to 1.05 CFM50 per $\mathrm{ft}^{2}$ of floor area. Older homes generally have higher ELAs. Eleven such houses on Long Island that had blower-door tests had specific effective leakage rates ranging from 5.6 to $12.1 \mathrm{~cm}^{2}$ per $\mathrm{m}^{2}$ of floor area, with the average being 8.4. The value for the house tested here was 9.4. This is consistent with values reported for upstate New York. [Strunk et al. 1996] It seems probable that a method of predicting envelope leakage from easily observed characteristics such as house size, age, style, geographic location, and state of repair could yield values of envelope leakage within $30 \%$ of the true value in most cases, which would be good enough for our purposes. 
In any event, Table 3 displays a broader range of values than Table 2, especially on the supply side. This is not surprising since less information was available as input. In terms of percentage of fan flow, the supply side leakage rates fall between $9 \%$ and $39 \%$ of fan flow, while the return side leakage rates fall between $19 \%$ and $49 \%$ of fan flow. On the basis of these numbers it can be said that return leakage is severe and supply leakage is moderate to severe. This would be sufficient basis for the homeowner to call in a duct repair expert to do a more accurate test and then make recommendations. The usefulness of the home test kit will depend on its ability, in the hands of a homeowner, to make the right call in the majority of cases about whether to get professional testing.

Table 3. Duct leakage values from home test kit, for all combinations of high and low duct pressure ratios.

\begin{tabular}{|l|l|l|}
\hline Test Condition & Supply Leakage $(\mathrm{cfm})$ & Return Leakage $(\mathrm{cfm})$ \\
\hline RB70, $S=0.7, \mathrm{R}=1.4$ & 177 & -267 \\
\hline $\mathrm{RB} 70, \mathrm{~S}=0.7, \mathrm{R}=1.8$ & 80 & -170 \\
\hline $\mathrm{RB} 70, \mathrm{~S}=0.9, \mathrm{R}=1.4$ & 248 & -338 \\
\hline $\mathrm{RB70}, \mathrm{S}=0.9, \mathrm{R}=1.8$ & 98 & -188 \\
\hline $\mathrm{RB} 80, \mathrm{~S}=0.7, \mathrm{R}=1.4$ & 228 & -318 \\
\hline $\mathrm{RB} 80, \mathrm{~S}=0.7, \mathrm{R}=1.8$ & 113 & -202 \\
\hline $\mathrm{RB} 80, \mathrm{~S}=0.9, \mathrm{R}=1.4$ & 319 & -409 \\
\hline $\mathrm{RB} 80, \mathrm{~S}=0.9, \mathrm{R}=1.8$ & 138 & -227 \\
\hline $\mathrm{RB} 90, \mathrm{~S}=0.7, \mathrm{R}=1.4$ & 252 & -341 \\
\hline $\mathrm{RB} 90, \mathrm{~S}=0.7, \mathrm{R}=1.8$ & 127 & -217 \\
\hline $\mathrm{RB} 90, \mathrm{~S}=0.9, \mathrm{R}=1.4$ & 352 & -442 \\
\hline $\mathrm{RB} 90, \mathrm{~S}=0.9, \mathrm{R}=1.8$ & 156 & -245 \\
\hline
\end{tabular}




\section{FURTHER RESEARCH NEEDS}

There is room for additional research here. Salient questions include:

o The pressures in the ducts are not measured by the home test kit. Fortunately, the calculation only requires the ratios of these pressures. It may be that further work using the House Pressure Test on a large number of houses will enable the ranges of these ratios to be narrowed, or perhaps it will be possible to develop correlations of the ratios with house characteristics that can be observed by eye. Even if this does not prove feasible, however, the test kit as is will give useful information in many if not most cases.

o The algorithm for calculating the duct leakages uses the house envelope leakage flow coefficient, which is measured with a blower door. Since this number will not normally be available to the homeowner unless an expert is already on the scene, a method of getting a rough estimate of this from the house size, age, style, geographic location, and condition will be needed. It is likely that some correlations of this kind can be developed. We are also looking for clever ways in which the test kit itself might be used to get a handle on this number.

What is the expected repeatability and accuracy of the home test kit, and is this sufficient to justify its promotion? If a false positive is defined as a case where the home test tells the homeowner to call for help where it isn't needed, and a false negative tells the homeowner that everything is in order when it really isn't, can the numbers of both kinds of false readings be kept acceptably low? How shall the test be structured to optimize the ratio of those false positives to false negatives that remain? Answering these questions will require field studies in which the home test kit is used on the same houses as other duct leakage test methods.

\section{REFERENCES}

Andrews, J.W. 1996. Field Comparison of Design and Diagnostic Pathways for Duct Efficiency Evaluation. Proc. 1996 ACEEE Summer Study on Energy Efficiency in Buildings, Monterey, CA, August 1996. American Council for an Energy-Efficient Economy, Washington, DC.

Andrews, J.W. and M.P. Modera. 1991. Energy Savings Potential for Advanced Thermal Distribution Technology in Residential and Small Commercial Buildings. BNL/LBL Report, Draft, July 1991.

ASHRAE 1997. Method of Test for Steady-State and Seasonal Values of Residential Thermal Distribution System Efficiency. Draft Standard 152P. American Society of Heating, Refrigerating, and AirConditioning Engineers, Inc., Atlanta, Georgia. 
Modera, M. and J. Byrne. Can a New Duct Test Take the Pressure? Home Energy, V. 14, No. 1, January/February 1997, pp. 29-33.

Strunk, P., M Stiles, L. Kinney, and T. Wilson. Stock Characterization and Energy Savings Potential in Forced Air Systems in Frostbelt Homes. Proc. 1996 ACEEE Summer Study on Energy Efficiency in Buildings, Monterey, CA, August 1996. American Council for an Energy-Efficient Economy, Washington, DC. 


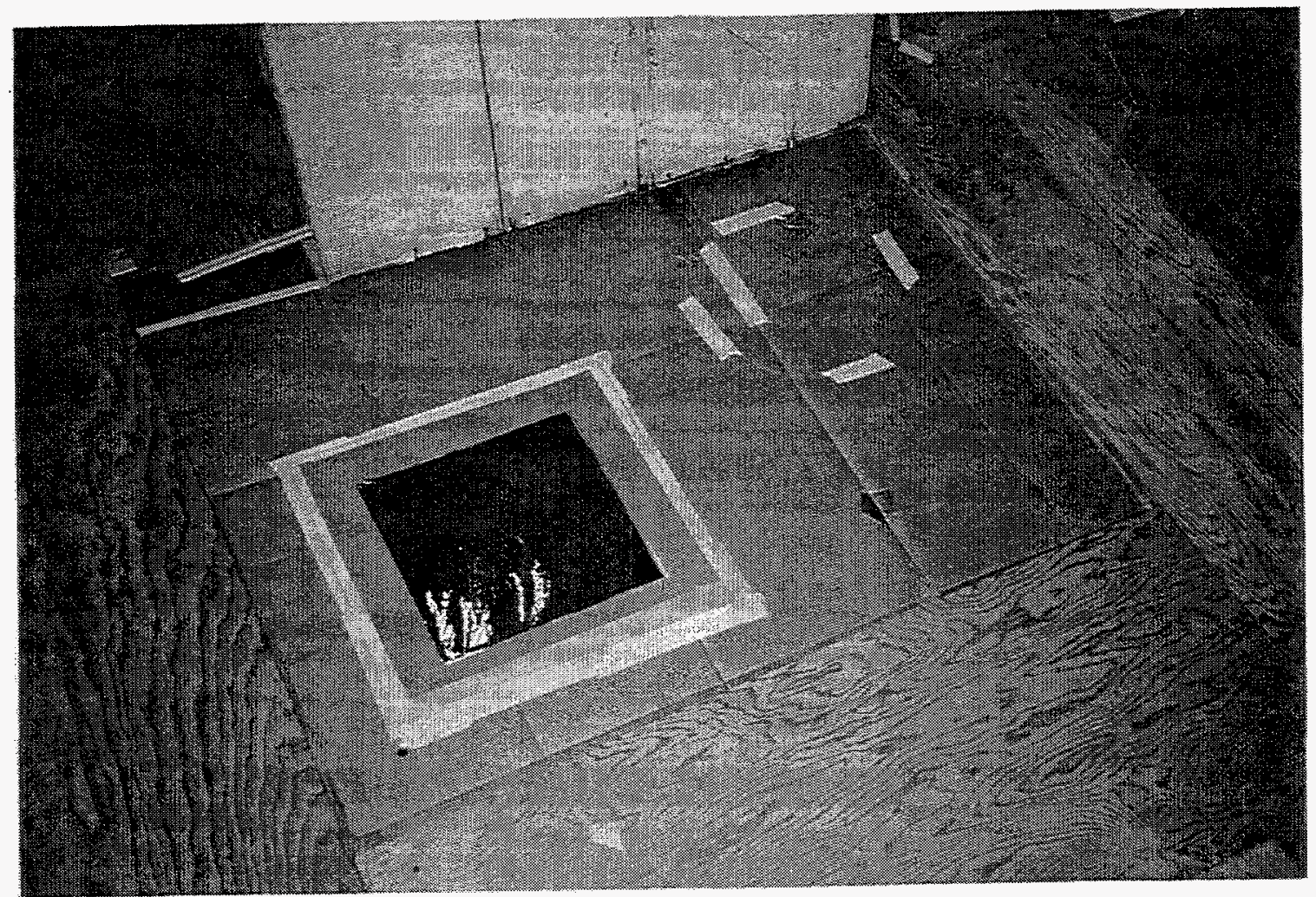

Figure 1. Home test kit in attic opening (top view)

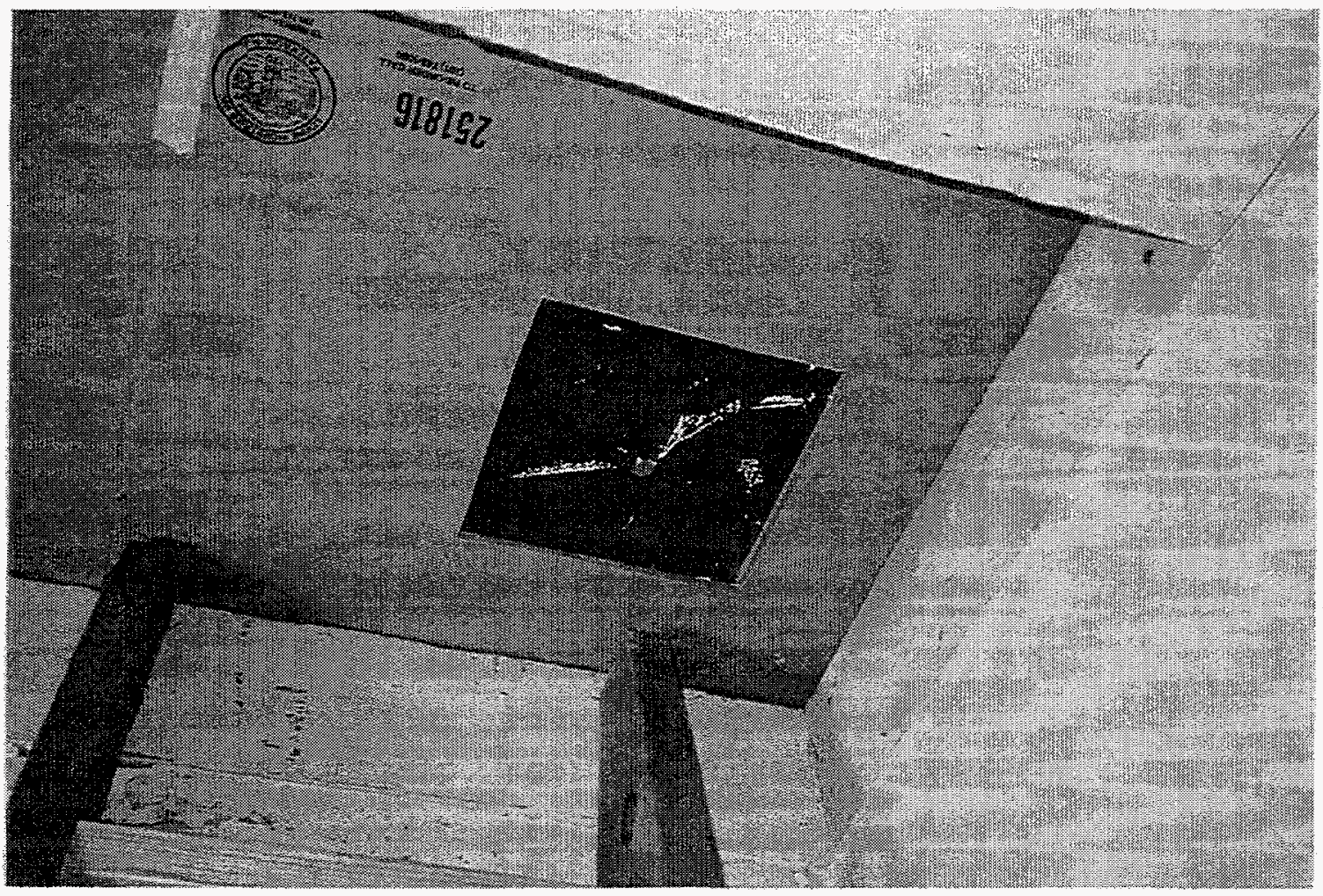

Figure 2. Home test kit in attic opening (bottom view). 


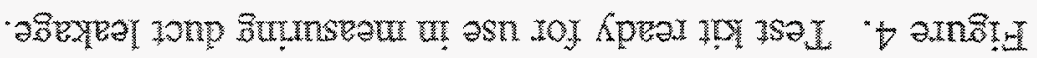

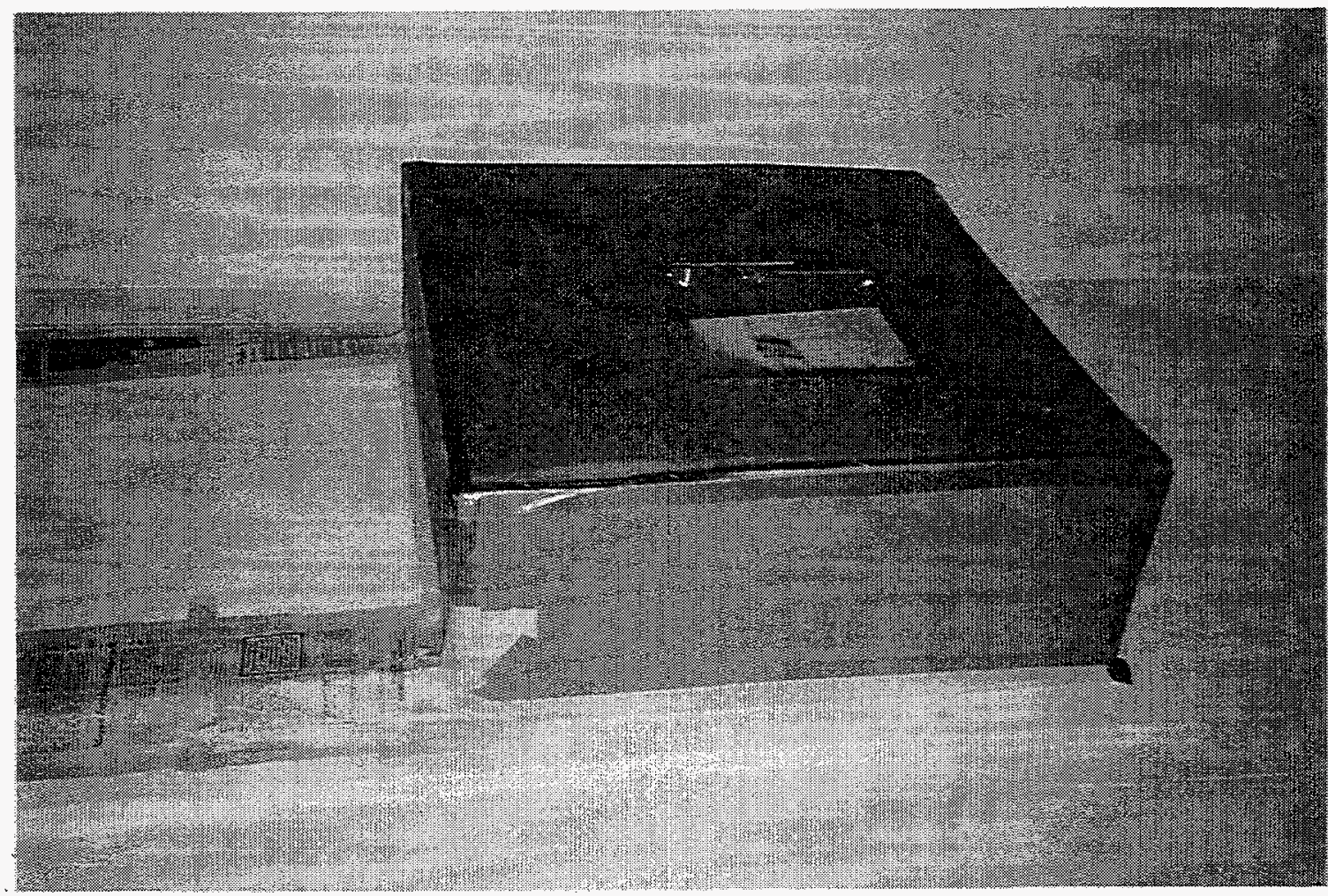

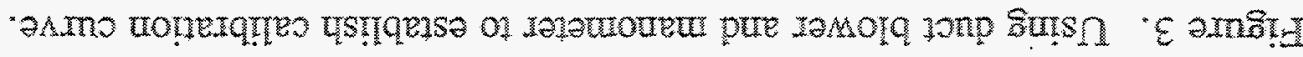

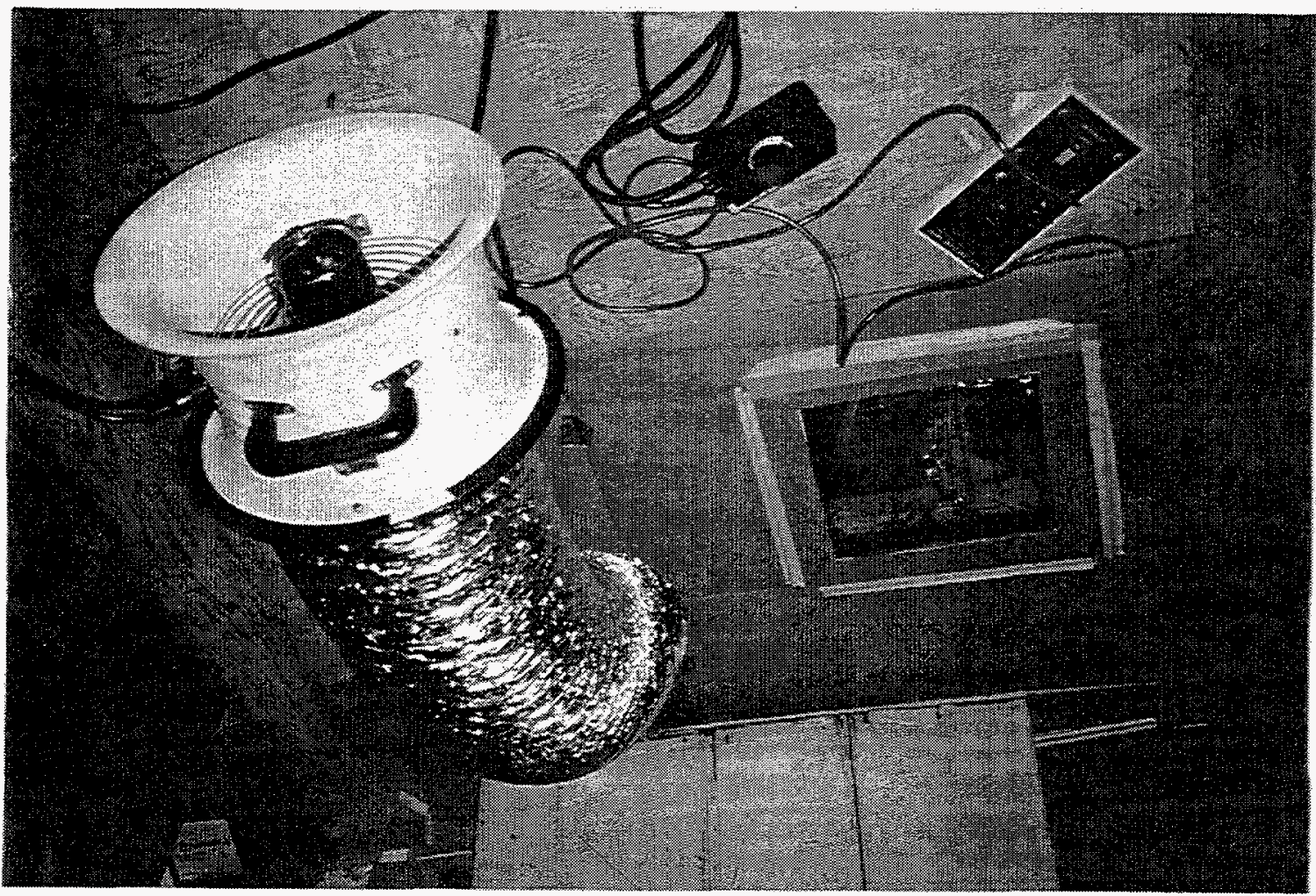




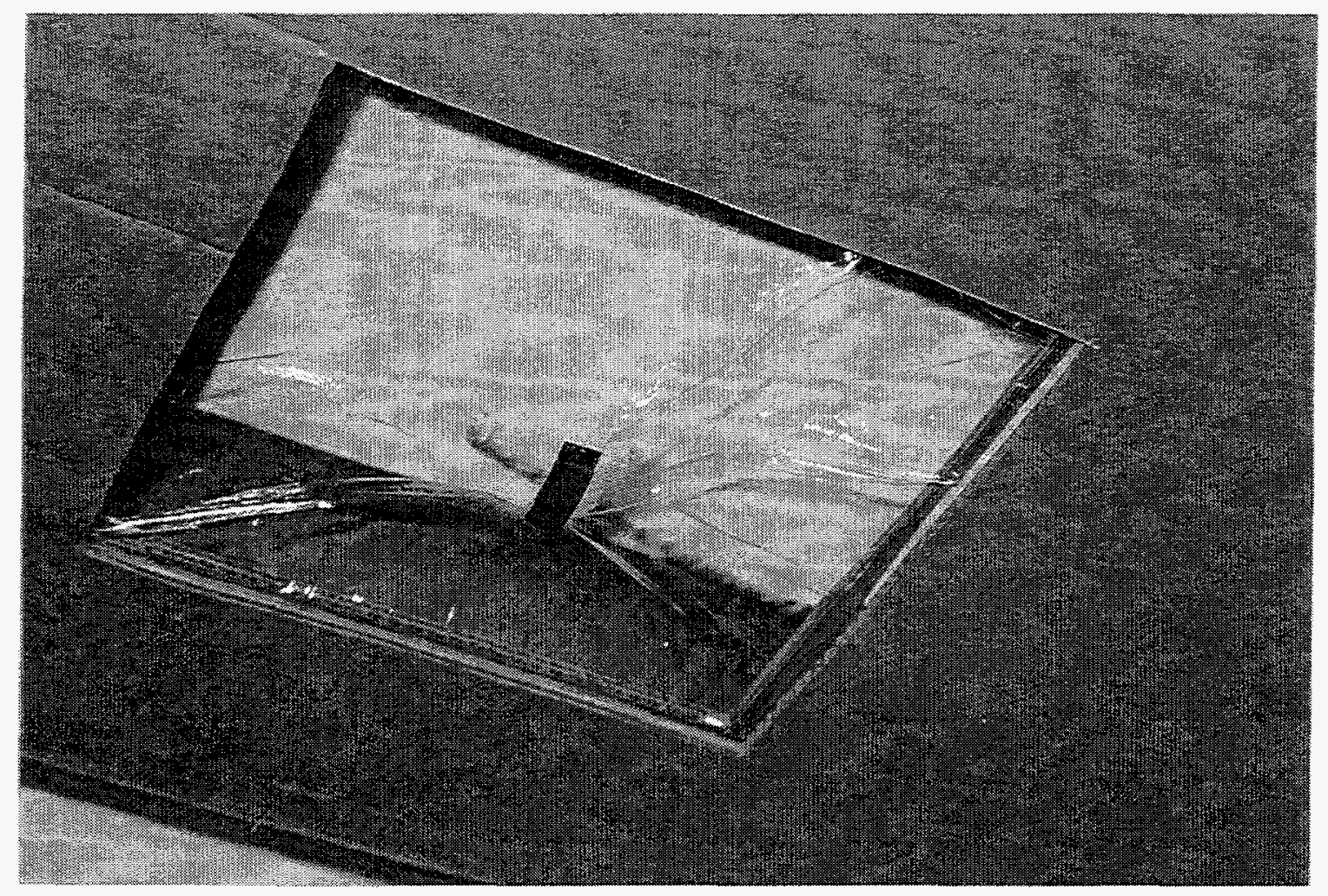

Figure 5. Closeup of magnet weights bringing plastic down to a neutral position. 